\title{
MENGURAI MAKNA KEMACETAN IBUKOTA \\ Dekonstruksi Wajah Kemacetan Jakarta Dalam Teks Koran Tempo.co “Ahok: Mobil Mewah Boleh Lewat Jalur Transjakarta, Asal...”
}

\author{
Ghanesya Hari Murti \\ Email:ghanesyaharimurti@yahoo.co.id \\ Fakultas Sastra, Universitas Negeri Jember \\ J1. Kalimantan 37 Jember \\ Jawa Timur 68121, Indonesia
}

\begin{abstract}
Abstrak
Analisa wajah kemacetan Jakarta dalam Koran Tempo.co "Ahok: Mobil Mewah Boleh Lewat Jalur Transjakarta, Asal..." merupakan upaya selebrasi pembacaan. Dekonstruksi sebagai cara baca menelanjangi teks mampu mengidentifikasi teks yang terpusat, final dan tertutup mampu dirayakan pemaknaannya. Konsep undecideable mempertontonkan bahwa rezim makna dan penyikapan kemacetan begitu ambigu, kabur sehingga memungkinkan untuk dijungkirbalikan secara hierarki metafisis yang menyimpan upaya penundukan. Differance hadir untuk menunda makna kemacetan yang sudah mapan dan penuh kepentingan nilai ekonomi politis, golongan, kelas, serta delusi kebaikan hati pemangku kuasa. Makna menjadi tersebar, meniadakan pusat dan memungkinkan terjadinya disemenasi sekaligus decentering dalam teks. Di sini, makna tidak lagi final tapi selalu menuju, mengada, berlari dan berkejaran menuju penanda-penanda.
\end{abstract}

Kata kunci: kemacetan, dekonstruksi.

\begin{abstract}
Analysis of traffic congestion in Jakarta in the newspaper faces Tempo.co " Ahok: Mobil Mewah Boleh Lewat Jalur Transjakarta, Asal..." is a term of reading celebration. Deconstruction as a way to read a text that reveals the seemingly centralized and closed meaning of the text to become more vulnerable to wider exposures. Undecideable as concept tends to show regime of meaning and attitude toward traffic congestion is ambiguous yet vague when inversion within metaphysical hierarchy affirms its hideous effort of submission. Differance functions to delay the established meaning of traffic congestion which is rife of economic value, political interests, group, class, and delusions of ruler's benevolent. The meaning is scattered and negated the center, allowing the dissemenation of meaning all at once decentering the text. Thus, the meaning is no longer final but always heading, becoming, running to the other signifier - signifier
\end{abstract}

Keywords: traffic congestion, deconstruction.

\section{Pendahuluan}

Kata kemacetan dalam konteks ibukota Jakarta selalu memberikan warna akan pemahaman yang beragam dalam hemat masyarakatnya. Kata macet yang identik dengan ibukota seperti menjadi sesuatu yang melekat dengan keseharian masyarakat 
urban, baik sebagai sebuah kebanggaan ataupun umpatan. Teks berita yang membahas mengenai masalah kemacetan yang selalu mengetengahkan isu mengenai seharusnya kemacetan disadari dalam ruang praktik politik ekonomi berikut usahanya memberikan solusi.

Wacana bahwa mobil mewah dapat menggunakan jalur khusus transjakarta menandakan pemaknaan kemacetan, berikut juga solusinya yang menarik untuk dikaji mengingat jalur Transjakarta memiliki fungsi untuk mengajak masyarakat untuk beralih dari kendaraan pribadi ke kendaraan umum. Berdasarkan pemahaman akan muatan makna kemacetan dalam teks berita Tempo:

"Ahok: Mobil Mewah Boleh Lewat Jalur Transjakarta" (http://www.tempo.co/read/news/2015/01/29/083638590/Ahok-Mob Dini Paramita diakses tanggal 29 Januari 2015), wajah kemacetan sepertinya diberi ruang yang sangat fragmentaris, sehingga apabila dipandang melalui oposisi biner ternyata mengandung kuasa yang politis dan ekonomis. Isu yang awalnya sebagai isu bersama berubah menjadi isu golongan yang bertendensi dalam melegitimasi ruang akses yang lebih baik terhadap kemacetan bagi golongan masyarakat tertentu dan didukung oleh pemegang kekuasaan. Dengan demikian kehadiran makna secara definitif dalam konteks politis adalah bukan hal yang bebas paksaan (Fayyadl, 2005:216-217).

Cara baca dekonstruksi dianggap sesuai sebagai usaha penjabaran makna kemacetan sebagai ikhtiar untuk mengungkap ruang dialektis diantara oposisi biner yang tidak alamiah. Teks yang selalu bersifat membangun diri, koheren dan terpusat ternyata selalu membawa cacat bawaan dalam mewartakan realita. Makna dari sudut pandang dekonstruksi menjadi sengkarut dan telanjang. Munculnya tafsir yang plural, tidak terbatas, dan sulit untuk direduksi dalam satu pemahaman yang tunggal menjadi ranah penting untuk membongkar selubung ideologis. Kerangka berpikir Derridian menyibak makna laten dibalik teks-teks yang tidak kosong dan berangkat dari sebuah teks sebagai jaringan keragaman kekuatan-kekuatan yang pesat dan referensinya yang tidak jelas (Derrida, 1982:230). Berangkat dari kacamata tersebut, dekonstruksi merupakan ikhtiar emansipasi teks dan tafsir yang mengada. Meminjam cara berfikir dan teknik analisis yang dihadirkan dalam tulisannya berjudul Given Time (Counterfeit Money), dekonstruksi makna kemacetan dalam teks berita Tempo.co 
berusaha dijabarkan dan dihadapkan pada persoalan makna yang kebenarannya selalu bersitegang dengan konsep pemikiran sekaligus menolak metafisika kehadiran. Problem kebahasaan dalam makna kemacetan dapat disimpulkan rumusan masalah yaitu bagaimana dekonstruksi kemacetan bekerja dalam teks Tempo.co "Ahok: Mobil Mewah Boleh Lewat Jalur Transjakarta, Asal...”. Dalam hal ini kemacetan yang dimaksud adalah makna sekaligus penyikapan kebijakan penanggulangannya.

\section{Kerangka Teoritis dan Metodologis}

Dekonstruksi dikenal sebagai sebuah cara baca yang tidak mempercayai pada penamaan dalam suatu korpus dan selalu menantang bagaimana sebuah teks diberikan sebagai sebuah bangunan solid dan general. Dekonstruksi melihat ada wilayah wajib 'guncang' yang tidak dapat dibendung karena korpus, teks, dan sebuah ujaran sederhana sangat memungkinkan untuk terbelah (Derrida, 2002:9). Sikap pembacaan Derrida memungkinkan emansipasi sebuah teks muncul, menjadi otonom layaknya teks karya sastra karena fungsi fakta kebahasaannya.

Derrida memiliki kerangka pemikiran yang khusus, yaitu menghindari segala konsep pemikirannya untuk dibakukan menjadi langkah-langkah yang metodis sehingga dirinya menolak pemikirannya dalam kerangka metode, namun cara kerja yang ditawarkan bukan berarti tidak memiliki keteraturan dalam membaca fenomena kebahasaan ${ }^{1}$. Runtutan tradisi Derridian termaktub dalam bukunya yang berjudul “Given Time (Counterfeit Money)” yang konsep pemberiannya (potlatch) dalam teks Marcel Mauss terpikirkan sebagai masalah bahasa. Momentum lahirnya dekonstruksi juga menandai problem masalah manusia pada dasarnya adalah bahasa. Berpijak pada tradisi Derridian yang memandang bahwa makna tidak bersifat total, maka bahasa

\footnotetext{
${ }^{1}$ Derrida berhati-hati untuk menghindari istilah ini [metode] karena konotasi proseduralnya adalah penghakiman. Seorang pemikir dengan metode telah memutuskan bagaimana menindaklanjuti, hal ini dimaksudkan Derrida sebagai sebuah ketidak bertanggung jawaban sendiri. Dengan demikian, perbincangan tentang metode dalam dekonstruksi, khususnya mengenai implikasi ethico-politik, akan mengkhianati cara berfikir Derrida, pemikiran lebih lanjut dapat dilihat pada "Derrida and The Political"oleh Berdworth, 1996 hal. 4. Di sini Derrida sebenarnya sangat terpengaruh oleh pikiran Nietzche, Husserl dan Heiddeger yang memahami adanya intensionalitas atau kehendak untuk berkuasa sehingga objek yang konon an sich dan menampakkan diri sebenarnya objek yang ditaklukkan.
} 
menjadi fokus masalah dalam teks tersebut, sehingga menyebabkan pemaknaan pemberian (potlatch) ternyata mengecoh penggunanya.

As in Melanesia it is a constant give-and-take." This latter expression, also in English in the original, is translated "donner et recevoir." So, translating "take" by "recevoir," Mauss continues: "The potlatch itself, so typical a phenomenon, and at the same time so characteristic of these tribes, is none other than the system of gifts exchanged" (Derrida, 1992:37)

Pemberian yang secara ideal sebaiknya dilandasi dengan kebenaran dan kejelasan, namun dalam teks tersebut ternyata menyimpan fungsi ganda. Kegiatan yang dianggap sebagai rasa sosial terhadap sesama manusia, ternyata selalu ada sebuah logika ekonomi di dalamnya, yang berdampak pemberian terkadang tidak bersifat tulus, namun mengharapkan pertukaran atau kembalinya modal atau hutang dengan sebuah rekayasa waktu. Pada tataran ini bahasa mengalami sebuah krisis makna, yang tidak dapat direduksi secara tunggal untuk membuktikan atau merealitakan kejadian. Ambiguitas penanda tidak lagi menujuk pada acuannya, sehingga klaim bahwa pemberian itu tulus beralih pada petanda baru yaitu hutang. Konsep tentang ambiguitas makna 'potlatch' ini kemudian dijabarkan oleh Derrida pada konsep undecidable. Derrida berhati-hati dalam menerjemahkan konsep undecidable yang sangat dekat dengan kata ketidakpastian, karena kata ketidakpastian memiliki implikasi negatif dan kekosongan, sedangkan yang dimaksudkan Derrida adalah gagasan tentang tidak mungkinnya suatu pemaknaan itu ditotalitaskan. Oleh sebab itu, apa yang tidak mungkin tertampung dalam makna sangat memungkinkan hadirnya penundaan atasnya, serta kemungkinan yang tidak terbatas atas sesuatu (makna) yang tidak mungkin (Royle, 2003:5). Tahapan ini melihat bahwa teks memiliki otonominya sendiri, dan sangat terbuka terhadap pemaknaan pembaca yang tidak dapat disatukan dalam kolektifitas. Derrida melihat adanya logosentrisme dalam cara berifkir secara terpusat yang berupaya untuk mengandaikan adanya kebenaran transendental yang bermukim di cara pandang dunia fenomenal. Logos sendiri merupakan pengarang yang berlindung dalam sistem metafisik, dan pledoinya sebagai subjek otoritas makna yang disampaikannya dalam teks (Fayyadl, 2005:16). 
Proses berfikir yang masih menganggap metafisika kehadiran sebagai kebenaran adalah rezim berfikir yang harus dijungkirbalikkan. Konsep ini sangat dominan dan khas strukturalisme Saussurian ${ }^{2}$.

Something promises itself as it escapes, gives itself as it moves away, and strictly speaking it cannot even be called presence. Such is the constraint of the supplement, such, exceeding all the language of metaphysics, is this structure "almost inconceivable to reason." Almost inconceivable: simple irrationality, the opposite of reason, are less irritating and waylaying for classical logic. (Derrida, 1976:154)

Sesuatu yang dianggap liyan di sini adalah ikhtiar Derrida memunculkan supplemen, tambahan yang mungkin hadir, kegilaan yang dulu pernah dianggap tidak dapat dibaca secara utuh dan diambil pengetahuannya dalam tradisi Saussurian. Proses pembalikan metafisik memberi ruang pertemuan karena supplemen menunjukkan bahwa mereka sebenarnya tidaklah hadir tetapi juga tidak absen (Derrida, 1976:154). Membunuh hierarki metafisis dapat diartikan, bahwa bahasa ternyata menemukan keberpihakannya sebagai rezim dan alat kuasa yang menghantui. Pembicaran tentang bahasa, sebagai instrumen kuasa melahirkan jejak yang terus menunda dan menangguhkan kehadiran kebenaran makna, melahirkan kemungkinan atas ketidakmungkinan (Fayyadl). Kembali kepada teks Mauss yang mempersoalkan masalah pemberian, lupa menjadi kata yang penting karena lingkaran pertukaran menjadi terputus dalam praktik pemberian.

he or she must also forget it right away l'instant] and moreover this forgetting must he so radical that it exceeds even the psychoanalytic categoriality of

\footnotetext{
${ }^{2}$ Konsep hirarki metafisis dan oposisi biner termaktub dalam buku “Pengantar Linguistik Umum” yang membahas masalah signifier-signified dan signifier selalu mengacu pada signified. Tradisi berfikir ini didekonstruksi oleh Derrida karena sifatnya yang arbitrer, konsensual dan sarat kepentingan kuasa, yang memungkinkan hadirnya subjek sebagai logos, atau pusat sehingga tercipta suasana kebahasaan yang tidak netral. Saussure jadi lebih mengutamakan tuturan ketimbang tulisan karena dia adalah tiruan tulisan (Sussure, 1996: 95). Dalam konsep lain Saussure lebih mengutamakan tema langue ketimbang parole, phonic di atas writing, sinkronik di atas diakronik yang cenderung lebih stabil dan sulit berubah dalam periode lama sehingga dapat diambil pengetahuannya. Namun Derrida akhirnya melihat bahwa hubungan bahasa yang dialektis, konsensual dan arbitrer itu justru yang menyebabkan signifier tidak pernah bisa mencapai signified dan akhirnya menggugurkan tradisi strukturalisme Saussure serta memulihkan tulisan ketimbang bunyi (Derrida,1976:31).
} 
forgetting. This forgetting of the gift must even no longer be forgetting in the sense of repression. (Derrida, 1992:16)

Pemberian yang tulus haruslah melupakan, karena lupa atau melupakan adalah proses intervensi logika ekonomi yang menghasilkan hutang tidak bekerja. Pemberian bukanlah lingkaran ekonomi, tulus merupakan syarat dan lupa menjadi praktik positif untuk menghilangkan hasrat hutang dan pertukaran.

Langkah pembalikan hierarki metafisik menghantarkan pada strategi differance yang dapat ditemukan dalam setiap sistem pemikiran, institusi, penafsiran, sejarah yang dibakukan (Fayyadl, 2005:111). Dalam teks Mauss, differance menjadi alat untuk melihat sebenarnya ada konsep ganti rugi, pengembalian, pertukaran, dan timbal balik. Konsep-konsep yang tidak absen namun tidak juga hadir ini yang menunda makna pemberian sebagai suatu kegiatan yang baik dan tulus.

For there to be a gift, there must be no reciprocity, return, exchange, countergift, or debt. If the other gives me back or owes me or has to give me back what I give him or her, there will not have been a gift, whether this restitution is immediate or whether it is programmed by a complex calculation of a long-term deferral or difference (Derrida,1992:12)

Bahasa menjadi problem ketika diberi nama sebagai representasi dari realita, 'potlatch' yang semata dianggap sebagai ritus pemberian ternyata tidak selalu bermakna seperti itu. Makna itu perlu diberi pembeda, ditunda dan diingatkan bahwa dia sebenarnya tidak secara alamiah dialami dan selalu memiliki kekurangan diri. Derrida mengingatkan bahwa ada realisme yang tidak tertangkap dan naif bila dilembagakan dalam bahasa berikut pemaknaannya yang absolut:

Differance is to be conceived prior to the separation between deferring as delay and differing as the active work of difference.... It is also inconceivable as the mere homogeneous complication of a diagram or line of time, as a complex "succession." The supplementary difference vicariously stands in for presence due to its primordial self-deficiency. (Derrida, 1973, 88)

Kemampuan supplemen dalam diri difference membuat adanya perbedaan juga sekaligus menunda. Mengingatkan hal ini tidak hanya dapat dibayangkan, sebagai sebuah komplikasi yang homogen tetapi sebagai rangkaian kompleks. Setelah 
konsumsi makna disadarkan pada sifat dasarnya yang selalu kekurangan, maka makna menjadi tersebar dan menyapa ruang ruang yang pernah ditinggalkan.

Makna yang tersebar menandakan adanya dissemenasi. Disemenasi mengurai makna, menjadikannya terbuka, tidak terperkirakan dan selalu terkait akan penulisan dan penafsiran ulang. Dalam teks Mauss, 'potlatch' bukan lagi bangunan yang rezimnya tidak tergoyahkan, tapi lebur dan hancur.

"it is not even a question of giving and returning, but of destroying, so as not to want even to appear to desire repayment. . . ." The trembling of this uncertainty affects the word "gift" but also the word "exchange" with which Mauss regularly associates it (Derrida, 1992, 46)

Pemberian dalam konsep potlatch harus dapat keluar dari lingkaran ekonomi, yaitu pembayaran hutang. Dengan kata lain melampaui hasrat pertukaran atau penggantian atas pemberian. Waktu menjadi suatu perbedaan, karena dalam diamnya ada pemberian yang mengharapkan hal serupa karena kepentingan logika ekonomi tidak berhenti bekerja. Hal ini menandakan pemberian menjadi masuk dalam prinsip ekonomi yang patut ditunggu kembalinya karena bersifat hutang. Rezim kebenaran atas potlatch melalui dekonstruksi telah menemui cermin-cermin baru, ruang tafsir baru dan pengalaman baru atas fenomena potlatch. Konsekuensi ini yang harus disikapi sebagai hasil pembacaan dekonstruksi, ketika makna tidak lagi mencapai pada konsep dasarnya, karena kebenarannya tidak selalu benar dari yang lain. Disemenasi adalah arena permainan yang terus bertransformasi dalam penanda-penanda, ketika makna terus menerus mendesak masuk dalam lingkaran yang berusaha dibangun namun tersebar berulang-ulang (Fayyadl, 2005:79).

\section{Hasil dan Pembahasan}

\section{Mencabar Isu Kemacetan Masyarakat Publik Perkotaan.}

If we are going to speak of it, we will have to name something. Not to present the thing, here the impossible, but to try with its name, or with some name, to give an understanding of or to think this impossible thing, this impossible itself. To say we are going to "name" is perhaps already or still to say too much. For it is perhaps the name of name that is going to find itself put in question.(Derrida, 1992:10) 
Memetakan realita dan memberikannya nama adalah usaha manusia untuk memberikan konsepsi pemahaman akan suatu hal yang sebenarnya tidak mungkin. Persoalan definisi kemacetan secara umum dapat dikategorikan sebagai fenomena, karena volume jalan lebih kecil daripada jumlah kendaraan yang melintasi sehingga menyebabkan pengendara/pengguna jalan menumpuk dalam satu titik. Hal demikian meletakkan isu ini sebagai isu publik perkotaan, yaitu Jakarta yang memiliki tingkat kepadatan lalu lintas yang sangat tinggi. Mendalami lebih lanjut ketika kemacetan menjadi isu bersama, regulasi yang membenarkan jalur khusus Transjakarta adalah halal aksesnya bagi sekelompok pengendara mobil mewah dengan syarat membayar sejumlah nominal. Ini adalah usaha mendefinisikan kemacetan dalam kerangka yang sangat fragmentaris, terfokus dan sektoral.

Menurut Ahok, rekannya itu hanya hendak menunjukkan bahwa dia memiliki uang dan menyiratkan mampu membayar berapa pun untuk masuk busway demi menghindari kemacetan. Ahok kemudian memiliki ide untuk membolehkan mobil mewah masuk jalur tersebut asalkan sanggup membayar. "Ada waktu tiga sampai lima menit bagi mereka melewati kemacetan. Kenapa tidak dimanfaatkan saja?" ujar Ahok. (http://www.tempo.co/read/news/2015/01/29/083638590/Ahok-Mob Dini Paramita diakses tanggal 29 Januari 2015)

Berpijak pada solusi kemacetan yang tertera dalam teks berita, terlihat bahwa kemacetan merupakan isu yang sangat mengganggu masyarakat kalangan tertentu saja, yang sebenarnya dapat ditangani dengan logika ekonomi. Isu kemacetan menjadi isu keberpihakan, dia dapat ditangani tapi prosesnya hanya dapat diaplikasikan kepada masayrakat kelas ekonomi tertentu. Hal ini menyebabkan konsep kemacetan menajadi tidak jelas referensinya. Konsep kemacetan menjadi tidak dapat diputuskan, intoleran dan terkotakkan. Masalah kemacetan menjadi layak, sah, dan wajar bagi masyarakat tertentu yang tidak mampu menggandeng kata mewah, mobil, dan rupiah untuk keluar dari lingkaran definisi ala ekonomi, sehingga ambiguitas akan muncul dan penting untuk didekonstruksi. Implikasi dari ambiguitas adalah menunda kehadiran definisi mutlak pada realitas macet sebagai masalah masyarakat urban. Differance menjadi strategi membongkar totalitas makna dalam teks yang berusaha membakukan makna, lalu menunda dan membedakan pada saat yang bersamaan sehingga kehadiran menjadi tidak mungkin (Fayyadl, 2005:110). Begitupula dengan kemacetan yang tidak 
dapat dipetakan dalam teks berita Tempo. Keretakan, keterputusan akan pemahaman dalam lingkaran isu publik saat ini bergeser pada isu kelas, ketika kata mewah dan mobil mengarah pada kemampuan kelas ekonomi atas. Kata rupiah juga menekankan pada logika ekonomi ketimbang logika sosial. Kehadiran makna kemacetan menjadi tertunda dan yang tersisa hanya jejak. Dalam hal ini kemacetan tidak dapat ditentukan maknanya. Mengutip kalimat berikut:

Gubernur DKI Jakarta Basuki Tjahaja Purnama atau Ahok mengeluarkan gagasan dibolehkannya mobil mewah melewati busway atau jalurbus Transjakarta. Namun ada syaratnya, yakni harus membayar dengan harga yang mahal. (http://www.tempo.co/read/news/2015/01/29/083638590/Ahok-Mob Dini Paramita diakses tanggal 29 Januari 2015)

Dampak kasus yang serupa, terlihat pada kata membayar dan mahal. Penunjukan serta pemilihan kata adalah tidak lain usaha intoleran terhadap yang tidak mampu secara ekonomi dalam menghindari kemacetan. Hemat pemahaman jalur transjakarta yang dulunya dibangun untuk lebih mengutamakan pemanfaatan kendaraan umum juga tercederai pemahamannya ketika mampu dibeli oleh masyarakat ekonomi atas yang lebih nyaman menggunakan kendaraan mewah pribadi. Kemacetan sekali lagi tertunda untuk dihadirkan sebagai keputusan tunggal yang dapat diatur dalam logika yang seolah total.

\section{Membeli Kemacetan, Membunuh Hierarki Metafisik}

Kerancuan kemacetan muncul ketika dia dihadapkan pada 'kesenjangan'. Kesenjangan menjadi isu lain yang tidak terelakkan ketika secara biner, metafisika kebenaran macet berpihak pada golongan-golongan yang diuntungkan secara posisi ekonomi. Inkosistensi dalam memandang isu kemacetan dari isu publik dan dikerucutkan menjadi isu golongan adalah upaya melihat satu sisi kemacetan melalaui logika politik ekonomi. Kemacetan yang ditanggulangi dengan logika membayar, mewah, mobil, pajak tinggi dan penggunaan jalur busway sebenarnya mengkhianati solusi kemacetan sebagai isu publik yang harusnya tidak hanya dinikmati sekelompok masyarakat tertentu yang sanggup membeli kemacetan. Solusi kemacetan dalam hemat ini menjadi terbuka, mengurangi makna dan acuan kemacetan sendiri karena adanya kesenjangan dalam oposisi biner yang dibangun. Bangunan metafisik yang 
memberikan hak khusus bagi kelas ekonomi tertentu terbukti sebagai sebuah kekerasan metafisik yang bersembunyi di balik jubah solusi akan adanya ketertitaban di ujung apabila hal ini terus dicanangkan. Derrida melihat bangunan hirarki metafisik sebagai kejahatan yang tidak membawa keadilan bagi oposisi yang dilemahkan dan tidak diuntungkan.

To do justice to this necessity is to recognize that in a classical philosophical opposition we are not dealing with the peaceful coexistence of a vis-a-vis, but rather with a violent hierarchy. (Derrida, 1981:41)

Secara dikotomis kalimat membeli, "Dia bilang, 'Saya, kan, bayar pajak Lexus Rp 28 juta. Itu besar dan mahal, lalu mengapa enggak bisa masuk jalur Transjakarta?' merupakan kalimat yang mengeksklusi masyarakat yang tidak bermobil dan membayar atau menyumbang lebih kepada pemilik kuasa. Kalimat tersebut memberikan ilusi bahwa isu kemacetan berikut solusinya adalah bukan isu publik yang dirasakan seluruh lapisan masyarakat. Terlebih bayangan akan logika bisnis menjadi penentu bahwa keberpihakan terjadi bagi yang mampu. Kemacetan tertunda kehadirannya sebagai masalah kemajemukan, karena hasrat logika ekonomi dan keuntungan yang dibangun dalam konstelasi metafisik.

kata Ahok, para pengendara mobil harus memasang perangkat elektronik atau e-money di dashboard mobil. "Sekali masuk busway harus bayar. Lama-lama, karena mahal, akhirnya jadi tertib," kata Ahok. (http://www.tempo.co/read/news/2015/01/29/083638590/Ahok-Mob Dini Paramita diakses tanggal 29 Januari 2015)

Penggunaan logika memainkan kata membayar dan ketertiban secara bersamaan di atas adalah usaha untuk menaklukkan. Konsep pengendara mobil yang membayar berujung pada tidak tertibnya penggunaan busway sebagai sarana publik yang semula dibangun diatas kepentingan umum ketimbang pribadi. Tuntunan bahwa ketertiban merupakan wilayah mendahulukan kepentingan umum daripada pribadi menjadi tidak dapat dijalankan. Kesenjangan akan muncul bagi pengguna non-mobil, dan bagi yang tidak mampu membayar. Terlebih lagi hal ini menandakan terbaginya hak pengguna busway yang berorientasi publik. Pemaknaan tertib menjadi kabur dan disalah gunakan oleh logika ekonomi. Mentalitas yang terbangun adalah usaha dan pemberian kesempatan untuk membeli kemacetan, bukan pemanfaatan sarana 
transportasi secara masal. Pembalikan hierarki metafisik atas kecenderungan yang diungkapkan melalui berangsur munculnya ketertiban justru menunjukkan permasalahan pokok kemacetan yaitu hilangnya konsistensi dalam memandang kemacetan, tidak jelasnya fungsi busway ketika memberi kesempatan bagi golongan tertentu, dan pemberian legitimasi pada masyarakat pengguna mobil mewah pribadi. Kata mewah/sederhana, mobil/sepeda motor, mampu/melarat, tertib/kacau, pajak tinggi/pajakrendah berkelindan dan berusaha menyeruak keluar dalam mengejawantahkan dirinya sebagai hal yang perlu turut diperhitungkan.

Ungkapan 'kompensasi' dalam kalimat 'Ahok muncul dengan membuat kompensasi untuk setiap kali melintas. Untuk pertama kali, ia menerapkan tarif Rp 50 ribu setiap kali masuk busway' sesungguhnya mengandung makna keberpihakan terhadap sekelompok masyarakat tertentu yang mampu membeli kemacetan, istilah kompensasi juga ternyata menentukan bahwa ini kebijakan sektoral. Tentu saja sepeda motor dan yang lain tidak mampu masuk jalur busway karena pajak yang diberikannya kepada pemerintah itu rendah daripada pajak mobil. Pembalikan hierarki metafisik mendaraskan adanya hak-hak pengguna kendara lain yang dilucuti dan halhal yang dilupakan. Dekonstruksi dengan ini menelanjangi cara berfikir yang pincang dan pandangan politik pemegang kuasa sehingga pandangan berkurangnya konflik kemacetan seakan menjadi dongeng dan delusi, mimpi bagi orang yang terenggut haknya dan tergerus oleh rezim pemaknaan kemacetan berciri khas pemangku kuasa.

Uang yang masuk tersebut, ujar dia, akan digunakan untuk meningkatkan kualitas dan kuantitas transportasi massal, seperti menambah jumlah bus tingkat gratis atau sarana bus Transjakarta.(http://www.tempo.co/read/news/2015/01/29/083638590/AhokMob Dini Paramita diakses tanggal 29 Januari 2015)

Pengecohan bahasa yang hadir secara struktural kembali tampil ketika yang dikatakan hasil uang ditukarkan dengan peningkatan kualitas dan kuantitas transportasi masal, padahal penambahan kendaraan umum yang diikuti dengan diberinya kesempatan bagi pengendara mobil tertentu juga tidak menutup kemungkinan akan menyumbang makin menurunnya volume jalan. Berarti kemacetan yang berusaha diperkirakan ternyata memiliki makna yang kontras. Solusi menanggulangi kemacetan secara hakikat ternyata bermuara pada kata kesenjangan. 


\section{Membongkar Kompensasi Kemacetan (Differance)}

Kompensasi kemacetan diibaratkan, sebagai kebaikan hati dari pemangku kuasa yang memberikan hak lebih bagi pengendara mobil untuk menghindari macet dengan menggunakan jalur bebas hambatan, busway asal mampu membayar sejumlah uang ynag tarifnya diramalkan akan terus melambung.

Ahok muncul dengan membuat kompensasi untuk setiap kali melintas. Untuk pertama kali, ia menerapkan tarif Rp 50 ribu setiap kali masuk busway. Jika belum ampuh mengurai kepadatan, tarifnya naik jadi Rp 100 ribu. "Kalau belum juga, akan dinaikkan lagi Rp 500.000.

(http://www.tempo.co/read/news/2015/01/29/083638590/Ahok-Mob Dini Paramita diakses tanggal 29 Januari 2015)

Pemanfaatan situasi kemacetan yang merugikan, dan tidak terjaminnya kelancaran dalam berkendara di ibukota disulap menjadi sebuah citra tindakan kebaikan hati dari penguasa. Solusi kemacetan berbasis nada kompensasi dimainkan dalam logika ekonomi politik penguasa dalam mengambil sikap kebijakannya yang dinilai pragmatis untuk mengurangi waktu dan angka kemacetan. Pemberian kesempatan akses jalur busway yang dibubuhi kalimat 'Uang yang masuk tersebut, ujar dia, akan digunakan untuk meningkatkan kualitas dan kuantitas transportasi massal' seolah mengisyaratkan bahwa penyalahgunaan jalur busway dalam rangka mengurai kemacetan adalah juga langkah baik untuk ikut serta dalam menyumbang dana bagi peningkatan dan pengadaan sarana transportasi publik. Adanya konsep ikut berpartisipasi, kebaikan hati dan mampu meminimalisir kemacetan adalah permainan bahasa yang sebenarnya rekayasa 'kompensasi'.

Diterimanya kompensasi sebagai solusi taktis mengurai kemacetan dan ikut menyumbang dana, sebenarnya adalah komersialisasi kemacetan. Kompensasi kemacetan diibaratkan sebagai 'benevolent' dari pemangku kuasa untuk memberikan hak lebih bagi pengendara mobil yang mampu memenuhi syarat dalam menngunakan jalur khusus busway. Kesadaran akan penggunaan kata kompensasi yang sebenarnya ambigu digunakan penguasa sebagai instrumen, akses, praktik, kuasa dalam memainkan logika ekonomi bagi masyarakat golongan 'mewah' yang ingin terhindar dari kemacetan, meskipun harus melangkahi kepentingan publik. Komersialisasi 
kemacetan menjadi padanan kata yang tepat dalam mengkontekstualisasikan kata kompensasi ketika kuasa diterapkan. Terlihat jelas bahwa solusi kemacetan seolah dinetralkan walau di balik kata itu terdapat selubung mental ekonomi yang tidak dapat lepas dalam pengambilan kebijakan.

\section{Disemenasi Makna Kemacetan dan Pluraritas Penyikapan}

Kajian makna kemacetan adalah upaya pemaknaan yang seyogyanya disikapi dalam konteks masyarakat luas, bukan kolektifitas masyarakat tertentu. Posisi maksud teks sebenarnya menggolongkan diri pada satu kelompok sosial yang mampu membeli makna kemacetan. Logika ekonomi politik ekonomi pemangku kuasa merujuk pada rasionalitas kuasa dalam kontrol isu sosial. Derrida mempersoalkan rasionalitas yang sebenarnya problematis, karena rasionalitas dalam ruang politis merupakan upaya uuntuk menaklukkan, efek dari permainan kuasa (Fayyadl, 2005: 216). Perbincangan tentang kemacetan ketika dikelompokkan sebagai representasi kolektif tertentu ternyata naï ${ }^{3}$, harapan juga semangat warga urban dalam menuntaskan problem kemacetan dengan komersialisasi tidak dapat dijadikan fondasi yang total tanpa retakan tapi harus ditunda kehadirannya, karena sangat tidak mungkin dikolektifkan. Makna menjadi tidak utuh tetapi tersebar dalam ruang-ruang lain yang terus terjalin, sangkarut dan tidak mungkin diberikan solusi. Realisme sinis yang menantang hermenutika naï ${ }^{4}$ dalam memandang kemacetan membawa kehancuran legitimasi

\footnotetext{
${ }^{3}$ Konsep representasi kolektif sangat lekat dengan Jugen Habermas yang memiliki semangat tentang representasi kehendak kolektif yang mengandalkan rasionalitas sebagai instrumennya. Hal ini ditentang keras oleh Derrida karena sangat tidak mungkin rasionalitas itu dikelompokkan menajdi satu kehendak karena rasio sendiri itu masalah yang sangat bermuatan politis. Debat antara Jugen Habermas dan Derrida tertuang dalam "Diskursus Filosofis Modernitas: Debat Jugen Habermas dan Jacques Derrida" Majalah Filsafat Driyakarya, tahun xxv no 2 hal 60. Penundaan menjadi mutlak dan tak dapat dihindari dan mengkhianati ruang publik yang ditawarkan Habermas. ${ }^{4}$ Konsep hermenutika naïf adalah runtutan sejarah panjang fenemenologi yang dicetuskan oleh Husserl hingga Heidegger yang menyoal masalah objek yang konon an sich ketika dihilangkan dari dunia pengalaman dan dikembalikan kembali ke dalam dunia empiriknya. Seolah objek mampu menampilkan dirinya ketika dibebaskan dari asumsi padahal manusia baru bisa berfikir ketika ada asumsi. Heidegger melihat bahwa secara keseharian kita ini adalah menafsir dan merupakan sifat khas manusia untung meneropong 'being'. Derrida berasumsi ini adalah kegiatan naïf karena dia melihat batasannya yang tak berujung dalam penafsiran itulah yang memungkinkan kita tidak mengetahui apa-apa sehingga konsep filsafati Derrida dalam menyikapi 'being' lebih sering disebut hermenutika radikal. Jejak pemikran radikalnya terangkum dalam tulisan John Caputo "Radical Hermeneutics: Repetition, Deconstrution, and The Hermenutic Project". Bloomington and Indiana Polis: Indiana Univseristy, 1987 hal. 157.
} 
metafisik yang telanjang. Dekonstruksi menghantarkan pada perjumpaan pada maknamakna yang terpinggirkan dan rasionalitas yang tidak sempat bertegur sapa.

What remains no doubt to be thought without alibi is precisely a differance without alibi, right there where, it's true, this same differance goes on endlessly producing irreducible effects of alibi through traces that refer to some other, to another place and another moment, to something else, to the absolute other, to the other to come, the event, and so forth. (Derrida, 2002:xvi-xvii)

Pemantapan diri dalam memaknai kemacetan berikut solusinya melahirkan efek yang selalu mengundang alibi kontrol kuasa. Efek dari dari dekonstruksi menjadi penyikapan kemacetan dalam tradisi berpikir komersil dalam melihat masalahmasalah perkotaan baru. Lahirnya ketimpangan dan kesenjangan dari penjungkiran legitimasi metafisik adalah contoh. Tujuan adiluhung yang dibungkus oleh rasionalitas membawa luka bawaan bagi kelompok masyarakat kalangan bawah yang harus rela menjadi kekutan rezim rasionalitas ekonomi. Di sini Derrida kembali mengingatkkan alasan nilai etika mendahului hukum (Fayyadl, 2005:217). Emansipasi teks lahir dari pemakanaan dan penyikapan atas masalah kemacetan yang tidak pernah dapat direduksi, oleh logika berfikir tunggal yang hendak dibakukan menjadi cara befikir kebenaran absolut. Kemacetan penting untuk dilihat aspek kontekstualnya yang terus menuju dalam ruang-ruang yang efek yang ingin disapa. Makna kemacetan memiliki hak otonom dalam memunculkan dirinya dalam diri masyarakat luas, bukan kolektifitas, golongan atau elit penguasa tertentu yang bermain dalam nilai pertukaran kemacetan. Kemacetan yang diperdagangkan menjadi lalim pada yang lain, sehingga dia tidak pernah mengacu pada satu hal yang jelas, tetapi lebih kepada fungsi penandapenanda.

\section{Simpulan}

Dekonstruksi Derrida terhadap makna kemacetan dan penyikapannya membuka tabir logika ekonomi yang berwujud komersialisasi kemacetan. Ketika logika ekonomi menjadi pusat perhatian dalam penuntasan masalah kemacetan sebenarnya merupakan bentuk sebuah alibi dari penguasa yang menggunakan premis kompensasi sebagai jalur represi kuasa. Pemaknaan ini berujung pada efek 
kesenjangan dan dapat dirasakan apabila kemacetan terjadi, ada sekian barisan sakit hati yang tereklusi dalam solusi taktis penuntasan kemacetan yang percaya apabila sejumlah pengendara mobil mewah membayar uang kompensasi akan menghasilkan ketertiban yang berangsur teratur. Dekonstruksi melihat kompensasi tidak lain adalah kemacetan yang 'ditiketkan' yang hanya menguntungkan sebagian golongan, sehingga hakekat kemacetan sebagai isu publik yang harusnya dapat dituntaskan dan dinikmati seluruh masyarakat bersama adalah semu. Alih-alih dana akan disalurkan sepenuhnya demi peningkatan sarana transportasi umum, namun secara etika masuknya mobil pribadi di jalur busway adalah pencedaraan terhadap fungsinya sebagai seruan peningkatan penggunaan transportasi masal. Terlebih akses kesempatan ini membuat frekuensi jalur busway semakin padat dan mengembalikan pada lingkaran kemacetan. Pemberian akses pribadi di atas publik menumbuhkan ego manusia yang memiliki hak lebih atas masyarakat pengendara lain. Masyarakat non-pengendara mobil tidak dapat menikmati ini, karena dia tidak dapat menyumbang pajak yang lebih tinggi daripada yang bermobil, tidak bermobil, tidak mewah, tidak mampu membayar 'tiket' yang terus melambung. Delusi dan alibi ikut menyumbang dalam jurang kesenjangan dimensi sosial masyarakat kota Jakarta yang semakin melihat bahwa rasionalitas ekonomi halal dikonversi dan diterapkan dalam logika sosial.

\section{Daftar Pustaka}

Derrida, Jacques. 1973. Speech And Phenomana.. Evanstone: Nortwestern University.

1976. Of Grammatology. Baltimore: John Hopkins University Pers. 1981. Positions. Chicago:The University of Chicago. . 1982. Margins of Philosophy. Chicago: The University of Chicago. 1992. Given Time, Counterfeit Money.Chicago:The University of Chicago.

.2002. I Have A Taste For Secret. Cambridge: Polity Press.

Fayyadl, Muhammad. 2005. Derrida.Yogyakarta: Lkis Pelangi Aksara. Royle, Nicholas. 2003. Jacques Derrida. London: Routledge.

Pramita, Dini. 2015. "Ahok: Mobil Mewah Boleh Lewat Jalur Transjakarta,Asal... ”(http://www.tempo.co/read/news/2015/01/29/083638 590/Ahok-Mob diakses tanggal 29 Januari 2015). 